\title{
Planning for The Utilization of Technological Pedagogical and Content Knowledge (TPACK) In Indonesian Language General Courses at Jakarta State Islamic University
}

\author{
Muhammad Viqi Rifai; Sumarwati; Atikah Anindyarini \\ Indonesian Language Education Master Program, Sebelas Maret University of Surakarta, Indonesia
}

http://dx.doi.org/10.18415/ijmmu.v8i12.3155

\begin{abstract}
Along with the development of technology, educators and lecturers should integrate learning with technology that involves pedagogical knowledge and mastery of the material. This framework is known as TPACK (Technology Pedagogy and Content Knowledge). This study aims to describe the planning for the use of TPACK in learning Indonesian Language as a general course at Syarif Hidayatullah State Islamic University Jakarta. The method used in this study is descriptive qualitative with a case study research strategy. The sources of data in this study are derived from: documents (RPS) and informants. The data validity used in this study is triangulation technique of data sources. The data analysis technique used in this study is the Miles and Huberman interactive model. The results of this study showed that the mastery of TPACK which includes mastery of PCK and TCK of lecturers at UIN Syarif Hidayatullah Jakarta is quite good. It can be seen from the following findings: (1) the ability of teachers to integrate technology has included various application media and Microsoft, (2) the learning resources used by teachers are not only in the form of text in books, magazines and other texts, but also in the form of video, audio and the surrounding environment. Based on the results above, it can be concluded that the development of TPACK for Indonesian language lecturers at UIN Syarif Hidayatullah Jakarta deserves appreciation.
\end{abstract}

Keywords: General Course Bahasa Indonesia; Planning; TPACK

\section{Introduction}

Technological developments in the 21 st century have had a great impact in education. The development of science and technology has changed the characteristics of students so that orientation and learning strategies require innovation. These changes include; orientation to needs, ways of learning, and learning models. The Covid-19 pandemic period during 2020 also made considerable changes in education field.

Along with the development of technology, educators and lecturers should integrate learning with technology that involves pedagogical knowledge and mastery of the material. This framework is known as TPACK (Technology Pedagogy and Content Knowledge). The components contained in TPACK include three domains (Koehler and Mishra, 2009:62) namely; material knowledge, pedagogical knowledge, and technological knowledge. Material knowledge involves understanding a content or 
teaching material. Pedagogical knowledge involves teaching and learning processes and learning strategies. This domain includes how teaching materials can be formulated into a concept so that it can be easily understood by students. Technological knowledge also involves information processing, communication, and problem solving (Koehlr, Mishra, and Cain, 2013:15).

TPACK was derived and elaborated to complete the learning needs of students. Targets who will be taught (students) has a major influence on what is taught (subject content) and how it is taught (pedagogy or technological tools). Meanwhile, the way of teaching plays a supportive role for instructional targets (learning objectives). It is even more complicated when TPACK is expected to be an edge knowledge framework that educators rely on to develop 21 st century student skills and competencies (Ying, 2015:11).

A study on the integration of learning and technology as reviewed by Fakomogbon and Bolaji (2017:268) showed that collaborative learning through smartphones can improve motivation and academic results. In addition, the use of smartphones can involve various kinds of knowledge, group discussions, and assessment groups with other groups. Further, the availability of digital technology is able to support formal learning methods (Kwok-Kwing and Smith, 2017: 115). Modern advanced technology such as computers, laptops, mobile phones, tablets; Google browser; and social media networks such as Facebook and Twitter are very popular among students so that they can be used as a complement to formal learning methods. Those technologies are expected to meet the diverse learning styles of students. Kivunja (2015:1) recommends higher education levels to utilize social media technology as an effective pedagogy to support effective learning, teaching, and assessment in the 21st century. This technology creates opportunities for experiential learning. Goradia (2018:47) argues that experiential learning can be a very effective way for cognitive processing because it involves reciprocal exchange of discourse among students to develop a deeper understanding of pedagogical content knowledge.

Technology-based learning is also needed in learning Indonesian language. Indonesian language has a very important position in this country, as a national language. Therefore, Indonesian has a main position over the other regional languages. It is stated in the 1945 Constitution in Chapter XV article 36 which states Indonesian language as the state language. Suyatno et.al (2017: 5) stated that Indonesian as a national language has four functions; 1) as a symbol of national pride, 2) national identity, 3) a bridge for citizens throughout Indonesia, 4) and being a unifier of the nation. Viewing in terms of its position, Indonesian language in the state has the several functions including; 1) as a state language, 2) a bridge to the international world, 3) a tool for science and technology for the benefit of the country's development, 4) a communication tool at the education level.

Indonesian language courses in higher education can actually be used as; 1) a vehicle for developing the mental attitude of students so that they are able to appreciate values into state life, 2) provide an inculcation of knowledge and attitudes regarding the position of the Indonesian language as a liaison for the nation and for the development of language for Science and technology, 3) related to textbased Indonesian language learning, students are able to provide innovations and solutions to problems in the life of the nation and state, 4) students are expected to be able to master Indonesian as a means of academic communication both verbally and in writing (Dikti, 2016).

Research on TPACK has been conducted by Hendra Yulisman, et.al (2019). The survey research involved 88 natural science educators in Banda Aceh City. Data regarding the TPACK ability of educators is obtained from multiple choice test questions. The distribution of questions is carried out directly through training activities. Data analysis was carried out by descriptive and inferential statistics (SEM-PLS modeling). The results of his study showed that the TPACK ability profile of junior high school science educators in Banda Aceh City was dominated by content knowledge (CK). The results of the SEM-PLS analysis show that CK, PK, and PCK directly and indirectly contribute to the formation of TPACK for science educators for junior high schools in Banda Aceh City. The government and education 
providers are expected to help educators to improve their ability to use technology effectively in learning activities in order to form a comprehensive TPACK.

The second study was conducted by Nogrion, et.al. The results of their showed that the TPACK Content Knowledge for Geography Educators in Solok Regency was in the medium category or with an average score of 51. Class $\mathrm{X}$ material questions were the most difficult questions for educators. The results of TPACK - Geography Educator Technology showed a moderate category. However, it is indicated that the presentation media displayed is the result of modifications from media that have been made by other people. Meanwhile, the TPACK - Pedagogic Educators based on performance in the implementation of learning has an average of 80.79 or is in the medium category with the relevance level of the RPS component with Process Standards is $100 \%$. Based on the data above, it is necessary to provide guidance to improve the mastery of class $X$ material for educators. Then, training to design learning presentation media based on Ms. Office Power Point and others made by themselves as well as strengthening in designing lesson plans based on the characteristics of students in their respective schools. The equation of the research carried out is to analyze the ability of educators' TPACK in learning activities in the classroom. However, the difference in this study is to describe the process of planning and implementing the TPACK framework in the online teaching learning more optimally at the higher education level.

Based on the description above, this study focuses on planning the TPACK framework in learning Indonesian courses at Syarif Hidayatullah State Islamic University. UIN Syarif Hidayatullah is an Islamic-based state university located in Jakarta. This study has obtained preliminary data that during the pandemic some lecturers had difficulty creating effective learning through the integration of ICT. This is due to several factors such as face-to-face adaptation online, the low interest of students in participating in distance learning, and the lack of knowledge of some lecturers about the application of ICT in learning. In addition, the Indonesian language department continues to make efforts to adapt and use ICT as the main means of learning during the Covid-19 pandemic.

\section{Research Method}

This study is a qualitative descriptive type research, which uses data collection by collecting pictures and words called qualitative methods. As for the possibility of all the things studied to be key (Moleong, 2001: 11). The strategy used in this study is a case study at UIN Syaif Hidayatullah Jakarta. Case studies are empirical investigations of real-life context phenomena (Yin, 2003: 18). The data used in this study is the use of TPACK learning in Indonesian language learning. The sources of data in this study are derived from: documents (RPS) and informants. In collecting data, this study used data collection techniques in the form of interviews, observations, and document analysis. The data validity used in this study is triangulation techniques. The triangulation used in this research is triangulation of data sources. The data analysis technique used in this study is the Miles and Huberman interactive model.

\section{Results and Discussion}

This section describes the planning for the use of TPACK in learning Indonesian language as a general course at Syarif Hidayatullah State Islamic University Jakarta. The following discussions are the presentation of the analysis:

\section{Planning for the Use of TPACK in Indonesian Language Learning as a General Course at Syarif Hidayatullah State Islamic University Jakarta}

The relationship between technology, content and pedagogy forms the cognitive abilities of students in the form of PCK and TCK is known as a manifestation of the use of TPACK in learning. To see the components of PCK and TCK, it can be done through observing the Rencana Pembelajaran Semester (RPS) or Semester Learning Plan because RPS includes components that build PCK and TCK 
as well as a reflection of how an educator teaches. Scope of assessment instruments in the RPS are 1) educators compose teaching materials in a coherent, logical, contextual, and up-to-date manner; and 2) the selection of learning resources and learning media in accordance with the materials and learning strategies. These two indicators are used to see the pedagogical abilities of educators in Indonesian language courses at UIN Syarif Hidayatullah Jakarta.

In this study, PCK is seen through the way educators arrange teaching materials in a coherent, logical, contextual, and up-to-date manner. Content or material prepared by educators is seen from the breadth and depth of teaching materials prepared by taking into account the potential of students. The preparation of teaching materials is ordered from simple to complex, easy to difficult, and or concrete to abstract which is adjusted to the learning objectives. In addition, PCK related to content or material is adapted to the context of life and the development of science and technology. The combination of pedagogical knowledge and content knowledge means that educators not only master the material or content, but also pedagogy in its material delivery. Effective learning requires understanding content and pedagogy. Basically, each content has compatibility with different learning methods.

The PCK ability of educators is also seen through the way educators plan learning activities. In distance learning during the Covid-19 pandemic, educators must be able to utilize media in the form of applications that can support the implementation of learning. Mastery of these media also needs to be considered by reviewing how effective the media is used for the smooth implementation of learning. In addition, learning activity plans designed by educators need to contain relevant learning strategies and methods to achieve learning objectives. It should be noted that the strategies and methods used in learning can make it easier for students to understand the material. The suitability of using strategies and methods based on the level of cognitive, affective, and psychomotor development of students is also included in the realm of pedagogical content knowledge. The following table provides an overview of the ability of educators in compiling teaching materials.

\begin{tabular}{|c|c|c|c|}
\hline RPS & Lecture Objectives & $\begin{array}{l}\text { Teaching } \\
\text { materials }\end{array}$ & Description \\
\hline 1 & $\begin{array}{l}\text { 1. Students are able to speak in scientific } \\
\text { presentations } \\
\text { 2. Students are able to understand the } \\
\text { development of the Indonesian language; } \\
\text { 3. Students are able to understand the use of } \\
\text { letters and words; } \\
\text { 4. Students are able to understand the } \\
\text { elements of absorption and punctuation; } \\
\text { 5. Students are able to use diction correctly; } \\
\text { 6. Students are able to make effective } \\
\text { sentences; } \\
\text { 7. Students are able to make paragraphs } \\
\text { correctly; } \\
\text { 8. Students are able to understand plagiarism; } \\
\text { 9. Students are able to make essay plans } \\
\text { 10. Students are able to reason correctly; } \\
\text { 11. Students are able to use scientific notation } \\
\text { quickly; } \\
\text { 12. Students are able to produce short writing } \\
\text { properly and correctly; } \\
\text { 13. Students are able to produce written } \\
\text { reproductions correctly; }\end{array}$ & $\begin{array}{ll}\text { 1. } & \text { Theory book } \\
\text { 2. } & \text { Internet } \\
\text { 3. } & \text { Videos } \\
\text { 4. Journal } \\
\text { 5. Newspapers } \\
\text { 6. Text of } \\
\text { speech } \\
\text { 7. Literary } \\
\text { 8. } \begin{array}{l}\text { works } \\
\text { 8. }\end{array} \\
\text { envirounding } \\
\text { entront }\end{array}$ & $\begin{array}{l}\text { The arrangement of } \\
\text { teaching materials is } \\
\text { based on the use of } \\
\text { learning resources in } \\
\text { the form of books, } \\
\text { various scientific } \\
\text { and non-scientific } \\
\text { discourses, audio- } \\
\text { visual media, and } \\
\text { contextual } \\
\text { environments that } \\
\text { can support the } \\
\text { achievement of } \\
\text { learning objectives. }\end{array}$ \\
\hline
\end{tabular}




\begin{tabular}{|c|c|c|c|}
\hline 2 & $\begin{array}{l}\text { 1. Students are able to speak in scientific } \\
\text { presentations } \\
\text { 2. Students are able to understand the } \\
\text { development of the Indonesian language } \\
\text { 3. Students are able to understand the use of } \\
\text { letters and words } \\
\text { 4. Students are able to understand the } \\
\text { elements of absorption, punctuation and } \\
\text { transliteration } \\
\text { 5. Students are able to use diction correctly } \\
\text { 6. Students are able to make effective } \\
\text { sentences } \\
\text { 7. Students are able to make paragraphs } \\
\text { correctly } \\
\text { 8. Students are able to understand plagiarism } \\
\text { 9. Students are able to make essay plans } \\
\text { 10. Students are able to reason correctly } \\
\text { 11. Students are able to use scientific notation } \\
\text { quickly } \\
\text { 12. Students are able to produce short writing } \\
\text { well and correctly } \\
\text { 13. Students are able to produce written } \\
\text { reproductions correctly }\end{array}$ & $\begin{array}{ll}\text { 1. } & \text { theory book } \\
\text { 2. } & \text { Internet } \\
\text { 3. } & \text { Videos } \\
\text { 4. } & \text { Journal } \\
\text { 5. } & \text { Newspaper } \\
\text { 6. } & \text { Speech text } \\
\text { 7. } & \text { Literature } \\
& \text { work } \\
\text { 8. } & \text { Surrounding } \\
& \text { environment }\end{array}$ & $\begin{array}{l}\text { The arrangement of } \\
\text { teaching materials is } \\
\text { based on the use of } \\
\text { learning resources in } \\
\text { the form of books, } \\
\text { various scientific } \\
\text { and non-scientific } \\
\text { discourses, audio- } \\
\text { visual media, and } \\
\text { contextual } \\
\text { environments that } \\
\text { can support the } \\
\text { achievement of } \\
\text { learning objectives. }\end{array}$ \\
\hline
\end{tabular}

Teaching materials are arranged from simple to complex, easy to difficult and/or concrete to abstract according to the learning objectives. The material studied by students is arranged from simple to complex. More, teaching materials are sufficient for the breadth and dept. The depth of teaching materials/materials is related to the use of learning resources used by educators. The table above shows that the objectives and utilization of the teaching materials used by the two lecturers are the same. The teaching materials in the RPS above are quite varied and have met the indicators, which include books, newspapers, articles, internet, texts, videos, and contextual environments. However, the use of the contextual environment has not been described in detail and clearly by educators. The description of the contextual environment to be used must be stated explicitly in the RPS. The use of varied learning resources in the RPS will be more optimal if educators make use of language laboratories, magazines, which are in accordance with the subject matter in competence. Likewise, the suitability of teaching materials with the context of life and the development of science and technology. Educators have used technology in learning although it needs to be optimized.

The preparation of teaching materials in RPS 2 is the same as in RPS 1 which is presented in a sequence from simple to complex, easy to difficult and/or concrete to abstract according to the learning objectives. The material studied is arranged from simple material to complex material. The breadth and depth of teaching materials prepared by educators are not optimal, variations in the use of learning resources are dominated by books and texts.

The use of learning resources used is dominantly textbooks rather than libraries, laboratories, field studies, the internet, and others. The use of varied teaching materials will facilitate the understanding of a material. Educators can use the surrounding environment as a learning resource, if internet use is still an obstacle. In addition, the use of relevant reading can be an alternative in a variety of learning resources. Educators can also use the environment around students as a learning resource. The use of the environment is easy for students to digest because the material presented is concrete. The use of the surrounding environment can be adapted to the material and make it easier for students to interpret or understand the subject matter. Utilization of varied and broad learning resources is part of the effort to obtain maximum learning outcomes. Learning resources are all supporting sources for learning activities, 
including support systems and materials, as well as a learning environment that can be used to facilitate learning activities and improve learning performance. Therefore, learning resources need to be developed and managed functionally, systematically, and well. Management of learning resources is part of the competencies of educators that need to be developed, these competencies are professional competencies. Based on the Regulation of the Minister of National Education Number 16 of 2007 concerning Standards of Qualification and Competence of Educators, it is stated that an educator must develop learning materials that are guided creatively. This ability is also related to PCK competence.

The aspects used in this study are to see how far the TCK of Indonesian language educators at UIN Jakarta is, namely the selection of learning resources/learning media in accordance with the materials and approaches/learning methods. As for the aspect assessment items used, namely the selected learning resources/learning media that can be used to achieve the learning objectives or competencies to be achieved; the selected learning resources/learning media can facilitate students' understanding; information technology is used as a learning resource/media; the use of technology as a learning resource/learning media that is selected according to the level of cognitive, affective, and psychomotor development of students. The following table 3 provides an overview of the ability of educators in choosing learning media.

\begin{tabular}{|c|l|l|l|}
\hline RPS & \multicolumn{1}{|c|}{ Media } & \multicolumn{1}{c|}{ Method } & \multicolumn{1}{c|}{ Description } \\
\hline RPS 1 & $\begin{array}{l}\text { Zoom, Google } \\
\text { classroom, } \\
\text { Whatsapp, Ms. } \\
\text { Power Point. }\end{array}$ & $\begin{array}{l}\text { Discussions, lectures, } \\
\text { questions and } \\
\text { answers, } \\
\text { assignments, } \\
\text { exercises and } \\
\text { practices. }\end{array}$ & $\begin{array}{l}\text { Learning activities using a scientific } \\
\text { approach with appropriate methods can make } \\
\text { it easier for students to understand the } \\
\text { material being studied. Core learning is in } \\
\text { accordance with the syntax of the method } \\
\text { used. }\end{array}$ \\
\hline RPS 2 & $\begin{array}{l}\text { Zoom, Google } \\
\text { classroom, } \\
\text { Whatsapp, Ms. } \\
\text { Power Point, } \\
\text { quiz. }\end{array}$ & $\begin{array}{l}\text { Discussion and } \\
\text { Assignment }\end{array}$ & $\begin{array}{l}\text { Lecturers use technology as a learning } \\
\text { medium in the form of distance learning } \\
\text { support applications and do not focus only on } \\
\text { Ms. Power point. }\end{array}$ \\
\hline
\end{tabular}

The ability to integrate technology in learning is still limited to PowerPoint. The use of technology in RPS 1 and 2 is optimal. The use of learning media has utilized applications and technology media as a support for distance learning. The use of technology as the chosen learning media is in accordance with the level of cognitive, affective, and psychomotor development of students. The use of technology in this learning needs to get serious attention, especially in the era of the industrial revolution 4.0. Based on Permendikbud No. 22 of 2016 concerning Basic and Secondary Education Process Standards, educators must be able to utilize information and communication technology to improve the efficiency and effectiveness of learning. The use of technology in learning can explore the competencies possessed by educators in the use of technology. Exploring the competence of educators in addition to knowledge, attitudes, and motivation is the ability to use technology that involves students. The use of technology has been suggested to facilitate optimally achieving learning objectives and optimizing the competencies possessed by educators. The implementation of technology and media that have been adapted and designed in such a way with learning materials can help students reach their highest potential, regardless of the innate abilities possessed by students.

Based on the analysis of the RPS above, educators have used technology media both visually and audio. Educators who have integrated technology in learning are endeavored to the maximum to support distance learning. In addition, educators have used and implemented online learning applications or 
websites (e-learning) in learning. Educators have also used online platforms for quizzes, educators are also not aware of any platforms that can be used for game-based quizzes on RPS 2. Besides making fun learning, the use of games in learning can improve students' skills. The use of games can improve the skills and character of students in learning Indonesian language.

Based on the description above, it can be concluded that teachers' mastery of TCK needs to be improved, especially in the aspect of applying technology in learning. The use of technology in learning can increase students' learning motivation, make learning more fun, provide more knowledge to students, facilitate the transfer of information that supports learning and make students active in learning. However, the implementation of learning becomes more efficient using information technology in language and literature learning and it has positive response. In addition, education in the era of the industrial revolution 4.0 demands the integration of information technology.

\section{Conclusion}

The results showed that the mastery of TPACK which includes mastery of PCK and TCK of lecturers at UIN Syarif Hidayatullah Jakarta is quite good. It can be seen from the following findings: (1) the ability of teachers to integrate technology has included various application media and Microsoft, (2) the learning resources used by teachers are not only in the form of text in books, magazines and other texts, but also in the form of video, audio and the surrounding environment. Based on the results above, it can be concluded that the development of TPACK for Indonesian language lecturers at UIN Syarif Hidayatullah Jakarta deserves appreciation. This study is limited to observing the Semester Lecture Plan or RPS which has been prepared by the lecturer. Research on TPACK can be supplemented by observing the implementation of the RPS in the classroom. Observation of implementation in class is carried out as proof or confirmation of the RPS that has been prepared by the lecturer.

\section{References}

Fakomogbon, M. A., \& Bolaji, H. O. (2017). Effects of Collaborative Learning Styles on Performance of Students in a Ubiquitous Collaborative Mobile Learning Environment. Contemporary Educational Technology, 8(3), 268-279.

Goradia, Tirta. (2018). Role of Educational Technologies Utilizing the TPACK Framework and 21st Century Pedagogies: Academics' Perspectives. IAFOR Jurnal of Education. Vol 6, no 3, hlm 47. Endeavour College of Natural Health, Australia.

Koehler, M.J., \& Mishra, P. (2009). What is Technological Pedagogical Content Knowledgen?. Contemporary Issues in Technology and Teacher Education, 9(1), hlm 62.

Koehler, M. J., Mishra, P., \& Cain, W. (2013). What Is Technological Pedagogical Content Knowledge (TPACK)?. Journal of Education, 193(3), hlm 15.

Kwok-Wing, L., \& Smith, L. A. (2017). Tertiary Students' Understandings and Practices of Informal Learning: A New Zealand Case Study. Australasian Journal of Educational Technology, 33(2), 115128.

Moelong, Lexy J. 2001. Metodelogi Penelitian Kualitatif. Bandung: Remaja Rusdakarya.

Suyatno, et al. 2017. Bahasa Indonesia untuk Perguruan Tinggi (Membangun Karakter Mahasiswa melalui Bahasa). Bogor: Penerbit IN MEDIA. 
Yulisman, Hendra, et al. (2019). The Contribution of Content, Pedagogy, and Technology on The Formation of Science Teachers TPACK Abilitiy. EDUSAINS.11 (2), 173-185. Universitas Pendidikan Indonesia.

Yin, R. K. (2003). Case Study Research Design and Methods (Third Edit). London: SAGE Publication Ltd.

\section{Copyrights}

Copyright for this article is retained by the author(s), with first publication rights granted to the journal.

This is an open-access article distributed under the terms and conditions of the Creative Commons Attribution license (http://creativecommons.org/licenses/by/4.0/). 